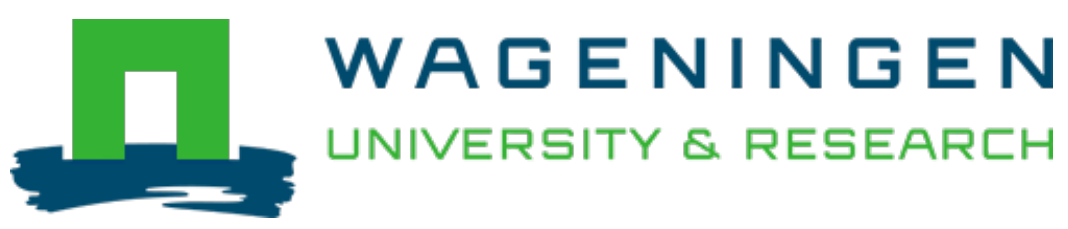

\title{
Identification of Solanum Immune Receptors by Bulked Segregant RNA-Seq and High-Throughput Recombinant Screening
}

\author{
Solanum tuberosum \\ Torres Ascurra, Yerisf; Lin, Xiao; Wolters, Pieter J.; Vleeshouwers, Vivianne G.A.A. \\ https://doi.org/10.1007/978-1-0716-1609-3_15
}

This publication is made publicly available in the institutional repository of Wageningen University and Research, under the terms of article $25 \mathrm{fa}$ of the Dutch Copyright Act, also known as the Amendment Taverne. This has been done with explicit consent by the author.

Article 25 fa states that the author of a short scientific work funded either wholly or partially by Dutch public funds is entitled to make that work publicly available for no consideration following a reasonable period of time after the work was first published, provided that clear reference is made to the source of the first publication of the work.

This publication is distributed under The Association of Universities in the Netherlands (VSNU) 'Article $25 \mathrm{fa}$ implementation' project. In this project research outputs of researchers employed by Dutch Universities that comply with the legal requirements of Article $25 \mathrm{fa}$ of the Dutch Copyright Act are distributed online and free of cost or other barriers in institutional repositories. Research outputs are distributed six months after their first online publication in the original published version and with proper attribution to the source of the original publication.

You are permitted to download and use the publication for personal purposes. All rights remain with the author(s) and / or copyright owner(s) of this work. Any use of the publication or parts of it other than authorised under article $25 \mathrm{fa}$ of the Dutch Copyright act is prohibited. Wageningen University \& Research and the author(s) of this publication shall not be held responsible or liable for any damages resulting from your (re)use of this publication.

For questions regarding the public availability of this publication please contact openscience.library@wur.nl 


\title{
Chapter 15
}

\section{Identification of Solanum Immune Receptors by Bulked Segregant RNA-Seq and High-Throughput Recombinant Screening}

\author{
Yerisf Torres Ascurra, Xiao Lin, Pieter J. Wolters, \\ and Vivianne G. A. A. Vleeshouwers
}

\begin{abstract}
The identification, understanding, and deployment of immune receptors are crucial to achieve high-level and durable resistance for crops against pathogens. In potato, many $R$ genes have been identified using map-based cloning strategies. However, this is a challenging and laborious task that involves the development of a high number of molecular markers for the initial mapping, and the screening of thousands of plants for fine mapping. Bulked segregant RNA-Seq (BSR-Seq) has proven to be an efficient technique for the mapping of resistance genes. The RNA from two bulks of plants with contrasting phenotypes is sequenced and analyzed to identify single-nucleotide polymorphism (SNPs) markers linked to the target gene. Subsequently, the SNP markers that are identified can be used to delimit the mapping interval. Additionally, we designed an in vitro recombinant screening strategy that is advantageous for analyzing a large number of plants, in terms of time, space, and cost. Tips and detailed protocols, including BSR-Seq, bioinformatic analysis, and recombinant screening, are provided in this chapter.
\end{abstract}

Key words Pattern recognition receptors (PRR), Receptor-like proteins (RLP), Receptor-like kinases (RLK), Nucleotide-binding site leucine-rich repeat (NLR), Resistance genes ( $R$ genes), Effectors, Genetic mapping, Bulked segregant analysis (BSA), Mapping, Effectoromics

1 Introduction

Potato (Solanum tuberosum L.) is a staple food for 1.3 billion people [1], and its global production is close to $400 \mathrm{Mt}$ yearly [2]. Unfortunately, potato is host to many pathogens that can affect all organs of the plant and diminish its production [3]. There are 35 economically important bacterial, fungal, and oomycete diseases of potato worldwide [4]. Among these, late blight, caused by the oomycete Phytophthora infestans, is the most pernicious, especially in developing countries [5]. It is estimated that the total cost due to losses and to control this disease is close to $€ 9.4$ billion per year 
$[6,7]$. Therefore, the development of new cultivars that are resistant to economically important diseases is essential.

Plants have evolved a recognition-based immune system to defend themselves against pathogens [8-10]. Pattern recognition receptors (PRRs) that are located on the cell surface recognize microbial associated molecular patterns (MAMPs) or apoplastic effectors and activate defense responses. Intracellular nucleotidebinding site leucine-rich repeat (NLR) proteins that are encoded by resistance $(R)$ genes recognize cytoplasmic effectors, also called Avirulence (Avr) proteins [8]. In case of late blight, potato breeders and researchers have relied mainly on the use of $R$ genes. More than $20 R$ genes have been cloned [11], and many of them have been introgressed into cultivars with initial success [12]. The first and only characterized PRR in potato is the receptor-like protein (RLP) ELR (elicitin response) that recognizes INFl elicitin from $P$. infestans. ELR overexpression results in enhanced resistance to the pathogen, although the resistance level is not as strong as most $R$ genes [13]. The suitable deployment of immune receptors in crop plants, particularly by stacking multiple receptors, seems to be the key to obtain a durable resistance against pathogens [14-17].

Traditionally, wild and cultivated relatives of potato have starred as plentiful sources of resistance in potato breeding programs [18]. For many years, techniques as field, greenhouse, and laboratory assays have been used to screen Solanum species for disease resistance [3]. In the last years, the effectoromics strategy has come onto the scene to accelerate identifying of resistance and understanding of plant immunity [11]. Effectoromics is a highthroughput functional genomic approach that uses mainly two Agrobacterium-based functional assays, agroinfiltration and PVX agroinfection, to transiently express effectors in plant cells and monitor for the occurrence of macroscopic cell death responses [19, 20]. Additionally, for apoplastic effectors or microbeassociated molecular patterns (MAMPs), it has been shown that infiltration of effector proteins or peptides also represents an efficient way to screen responses [21].

The map-based cloning strategy has commonly been used to identify $R$ genes in potato [12, 22-24], and, in combination with the effectoromics approach, it has allowed the rapid cloning of various $R$ genes and a surface immune receptor against late blight, like Rpi-stol, Rpi-ptal, and ELR, respectively [13, 25]. The central procedure of map-based cloning is the genetic mapping of the target gene, which is performed in a segregating population, using molecular markers distributed along each chromosome to identify markers delimiting the genetic region that contains the target gene [26]. Then, new markers are developed within the region and used to identify recombinants from a much larger population. These recombinants are then phenotyped/tested for response/resistance to narrow the genetic interval down in a 
process called fine mapping [26]. The final goal of fine mapping is to determine a sufficiently small interval that allows the prediction of candidate genes. For potato, the whole process used to take several years, but fortunately, with the emergence of nextgeneration sequencing (NGS) technologies [27, 28] and the availability of the potato genome sequence [29-31], new strategies can be used to shorten this process [32].

Bulked segregant analysis (BSA) is an efficient method to identify markers linked to any gene or genomic region. In BSA, two bulks of plants with contrasting phenotypes for a specific trait are generated and analyzed to identify markers that discriminate the bulks [33]. BSA is a flexible approach that can be assisted by NGS technologies for the development of molecular markers [34]. Bulked segregant RNA-Seq (BSR-Seq) was developed as a new genetic mapping strategy by combining BSA and RNA-Seq [35] and has recently been used to accelerate the mapping of genes of interest [36-38]. RNA-Seq is commonly used for gene expression profiling but also for identification of single-nucleotide polymorphism (SNPs) that can be used as molecular markers $[39,40]$. Compared to whole-genome sequencing, RNA-Seq requires a lower sequencing depth and additionally provides useful gene expression data from the candidate genes [34]. When required, this strategy is followed by fine mapping. To gather the necessary number of recombinants, a large number of individuals from the population (usually a few thousand) have to be genotyped with flanking markers. This is typically time consuming and requires a large amount of space and labor in a greenhouse facility. By screening for recombinants in vitro before transferring plants to the greenhouse, the efficiency of this process can be much improved. In this chapter, we describe a detailed protocol for BSR-Seq and the subsequent high-throughput recombinant screening under in vitro conditions to facilitate and accelerate the fine mapping of immune receptors in potato.

\section{Materials}

\subsection{Sowing of Potato Seeds Under In Vitro Conditions and Micropropagation of Plants}

1. $70 \%$ Ethanol.

2. $1.5 \%$ Sodium hypochlorite.

3. Sterilized tap water.

4. MS20 medium: $4.4 \mathrm{~g}$ of Murashige and Skoog basal salt mixture (including vitamins) and $20 \mathrm{~g}$ of sucrose dissolved in $900 \mathrm{~mL}$ of double-distilled water $\left(\mathrm{ddH}_{2} \mathrm{O}\right)$. Adjust $\mathrm{pH}$ to 5.6 using $\mathrm{KOH}$ or $\mathrm{NaOH}$, and complete the volume to $1 \mathrm{~L}$. Add $8 \mathrm{~g}$ of micro agar and autoclave.

5. $100,000 \mathrm{ppm}$ Gibberellic acid $\left(\mathrm{GA}_{3}\right)$ stock solution: $1 \mathrm{~g}$ of $\mathrm{GA}_{3}$ dissolved in $10 \mathrm{~mL}$ of $\mathrm{ddH}_{2} \mathrm{O}$. Filter-sterilize. 
2.2 RNA Isolation

\subsection{DNA Isolation}

\subsection{Genetic Mapping}

1. RNeasy Plus Mini Kit, Qiagen.

2. Spectrophotometer for DNA/RNA quantity/purity evaluation.

1. CTAB buffer: $100 \mathrm{~mL} 1 \mathrm{M}$ Tris- $\mathrm{HCl}(\mathrm{pH} 7.5), 140 \mathrm{~mL}$ of $5 \mathrm{M}$ $\mathrm{NaCl}, 20 \mathrm{~mL}$ of $0.5 \mathrm{M}$ EDTA $(\mathrm{pH} 8.0), 740 \mathrm{~mL}$ of Milli-Q water, and $20 \mathrm{~g}$ of cetyl trimethylammonium bromide (CTAB) in $1 \mathrm{~L}$ of $\mathrm{ddH}_{2} \mathrm{O}$.

2. RNase $20 \mathrm{mg} / \mathrm{mL}$ (add $1 \mu \mathrm{L} / \mathrm{mL}$ of CTAB buffer just prior to use).

3. $\beta$-Mercaptoethanol (add $2 \mu \mathrm{L} / \mathrm{mL}$ of CTAB buffer just prior to use).

4. Chloroform:isoamyl alcohol $(24: 1[\mathrm{v} / \mathrm{v}])$.

5. Isopropanol.

6. $70 \%$ Ethanol.

7. Milli-Q water.

8. TissueLyser II and steel beads $(3.2 \mathrm{~mm})$.

9. Polypropylene cluster tubes: $1.2 \mathrm{~mL} 8$-tube strips and strip caps, assembled in 96-tube racks.

1. LightScanner System (BioFire) or any other suitable device for high-resolution melting analysis.

2. LC Green Plus (BioFire).

3. Phire Hot Start II DNA Polymerase (Thermo Fisher Scientific).

4. White-96-well plates (4titude).

5. Restriction enzymes (see Note $\mathbf{1}$ ).

6. QIAquick PCR purification kit (Qiagen).

7. Genomic resources: CAPS Designer (Sol Genomic Network, https://solgenomics.net/tools/caps_designer/caps_input.pl), Potato reference genomes of DMl-3 516 R44 (http:// solanaceae.plantbiology.msu.edu/pgsc_download.shtml), and Solyntus (https://www.plantbreeding.wur.nl/Solyntus/).

\section{Methods}

\subsection{Bulked Segregant RNA-Seq}

1. Identify diploid Solanum genotypes that respond to a specific effector or that are resistant to a certain pathogen (R), as well as genotypes that do not respond or that are susceptible (NR).

2. Generate a mapping population by crossing the $\mathrm{R}$ and $\mathrm{NR}$ genotypes (see Note 2 ).

3. Select $30 \mathrm{R}$ and $30 \mathrm{NR}$ individuals (see Note 3 ). 
4. Sample leaves from the R parent, NR parent, $30 \mathrm{R}$ plants, and 30 NR plants. Freeze the leaves in liquid nitrogen and store at $-80{ }^{\circ} \mathrm{C}$ until use.

5. Isolate RNA using the RNeasy Plus Mini Kit from Qiagen following the manufacturer's instructions, and remove genomic DNA using the gDNA eliminator columns (part of RNA isolation kit) or by on-column DNase digestion using RNasefree DNase Set (Qiagen). Evaluate the quantity and purity of the RNA using a spectrophotometer, and use $1 \mu \mathrm{L}$ of sample for gel electrophoresis to evaluate RNA integrity (see Note 4).

6. Prepare four samples: (1) R parent, (2) R bulk (mix equal amounts of RNA from the 30 R plants), (3) NR parent, and (4) NR bulk (mix equal amounts of RNA from the $30 \mathrm{NR}$ plants) ( see Note 5 ).

7. Send the RNA samples for sequencing (see Note 6 ).

An overview of the BSR-Seq strategy is shown in Fig. 1.
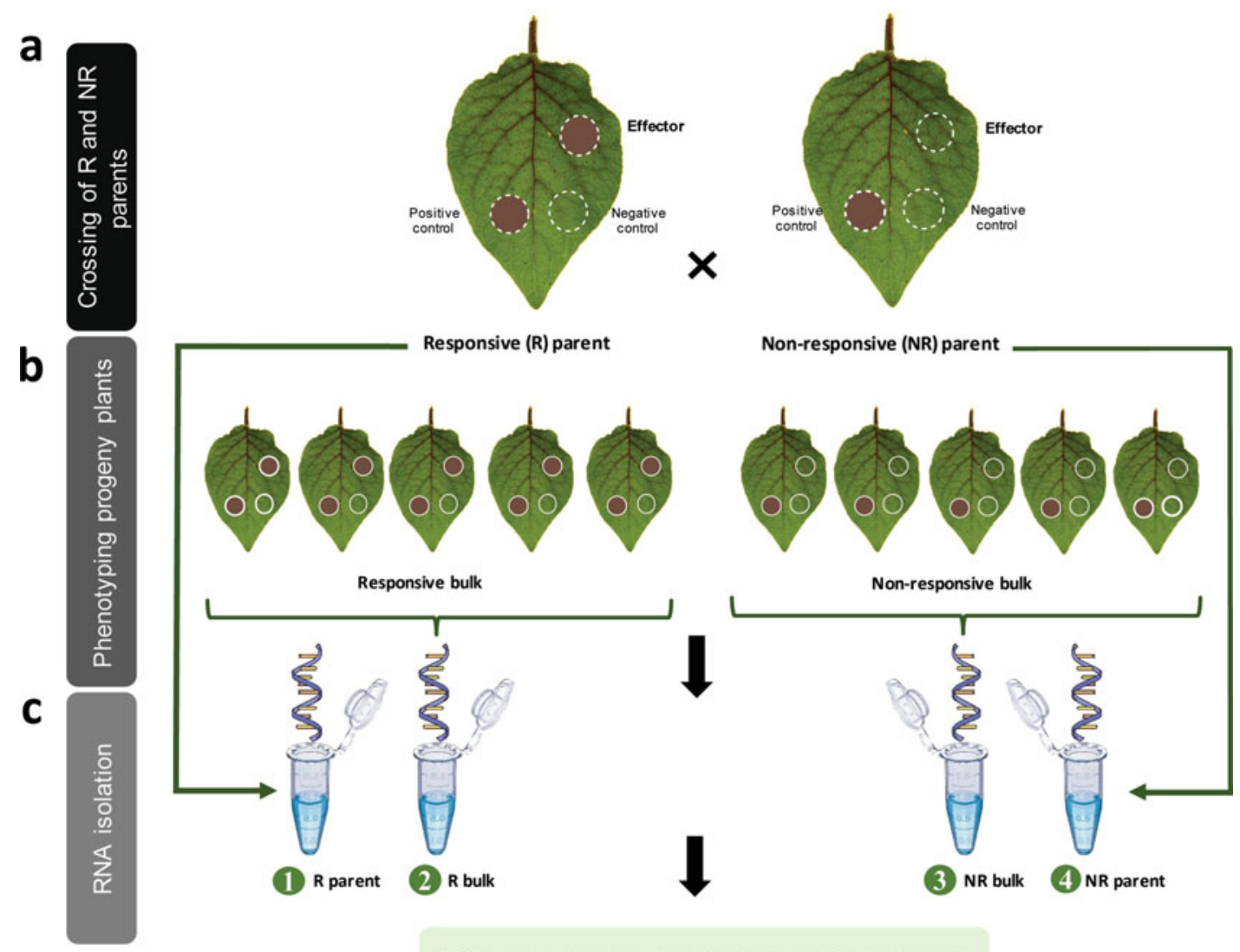

RNA sequencing and bioinformatic analysis

Fig. 1 Bulked segregant RNA-Seq strategy to map Solanum immune receptors. (a) Selected responsive (R) and nonresponsive (NR) genotypes are crossed to generate a segregating population. (b) Progeny plants with clear and confirmed phenotypes are selected to form the R and NR bulks. (c) Leaves are collected to form four samples, i.e., $R$ parent, $R$ bulk, NR parent, and NR bulk; the RNA is isolated and sent for sequencing 


\subsection{Bioinformatic Analysis}

\subsection{Genetic Mapping and Marker Development}

3.3.1 High-Resolution Melting (HRM) Markers

3.3.2 Cleaved Amplified Polymorphic Sequence Markers (CAPS)
1. Process the fastq files to remove adapter sequences, bad reads, and low quality bases using software such as fastp [41].

2. Map RNAseq reads to the reference of choice using a spliceaware aligner like STAR [42].

3. Use the alignment files for variant calling and identification of SNPs (VarScan) [42].

4. Filter for putative SNPs linked to response or resistance (heterozygous in the responding/resistant parent and progeny pool, while absent or homozygous in the non-responding/ susceptible parent and progeny pool).

From identified SNPs (see Subheading 3.2), develop molecular markers covering the complete mapping interval (see Note 7):

1. Design primers to target the previously identified SNPs, and test them in the parents and a small set of $\mathrm{R}$ and NR plants using one of the methods described below (see Note 8).

2. Analyze the population with the selected markers to identify the flanking markers.

1. Design a PCR primer set producing ideally an 80-120 bp (base pair) fragment ( see Note 9 ).

2. Prepare a $10 \mu \mathrm{L}$ PCR reaction: $5.0 \mu \mathrm{L}$ Milli-Q water, $2 \mu \mathrm{L}$ Phire Reaction Buffer, $0.4 \mu \mathrm{L} 5 \mathrm{mM}$ dNTPs, $0.25 \mu \mathrm{L}$ of each $10 \mu \mathrm{M}$ primer, $1 \mu \mathrm{L} \mathrm{LC-Green}{ }^{\circledR}$ Plus, $0.1 \mu \mathrm{L}$ Phire Hot Start II DNA Polymerase, and $1 \mu \mathrm{L}$ of genomic DNA (10-20 ng).

3. Dispense the solution in white-well PCR plates, and add $20 \mu \mathrm{L}$ of mineral oil.

4. Use the following PCR conditions: $98^{\circ} \mathrm{C}$ for $30 \mathrm{~s}$ followed by 40 cycles of PCR amplification $\left(98{ }^{\circ} \mathrm{C}\right.$ for $5 \mathrm{~s}$, Ta (annealing temperature) for $10 \mathrm{~s}$, and $72{ }^{\circ} \mathrm{C}$ for $15 \mathrm{~s}$ ) and terminated by an incubation at $72{ }^{\circ} \mathrm{C}$ for $60 \mathrm{~s}$ and $25^{\circ} \mathrm{C}$ for $30 \mathrm{~s}$.

5. Run the samples in the LightScanner and perform the HRM analysis to genotype the samples.

1. Design a PCR primer set producing ideally a 500-1,000 bp fragment. Target informative SNPs or another region inside the mapping interval.

2. Prepare a $15 \mu \mathrm{L}$ reaction: $11.3 \mu \mathrm{L}$ Milli-Q water, $1.5 \mu \mathrm{L}$ reaction buffer, $0.6 \mu \mathrm{L} 5 \mathrm{mM}$ dNTPs, $0.3 \mu \mathrm{L}$ of each $10 \mu \mathrm{M}$ primer, $0.06 \mu \mathrm{L}$ DreamTaq DNA Polymerase, and $1 \mu \mathrm{L}$ of genomic DNA (10-20 ng). Dispense the solution in standard PCR plates.

3. Use the following PCR conditions: $95{ }^{\circ} \mathrm{C}$ for $3 \mathrm{~min}$, followed by 35 cycles of PCR amplification $\left(95^{\circ} \mathrm{C}\right.$ for $30 \mathrm{~s}$, Ta for $30 \mathrm{~s}$, 
and $72{ }^{\circ} \mathrm{C}$ for $1 \mathrm{~min}$ ), and terminated by an incubation at $72{ }^{\circ} \mathrm{C}$ for $10 \mathrm{~min}$.

4. Run $3 \mu \mathrm{L}$ of PCR product on a $1 \%$ agarose gel, and verify the presence of single bands for the parents. Purify and sequence the PCR products of both parents using the QIAquick PCR purification kit or any other.

5. Find the most suitable restriction enzymes using the CAPS Designer tool (see Note 10).

6. Digest all the PCR products using the selected restriction enzyme, and run $5 \mu \mathrm{L}$ of the digested sample on a $1 \%$ agarose gel.

7. Determine the marker polymorphisms and genotype the plant samples. For each marker, analyze the band pattern of the parents and score the population accordingly.

3.4 High-Throughput Recombinant Screening

3.4.1 In Vitro Sowing of Seeds
To narrow down the mapping interval, the screening of a few thousand of plants from the population is required. The plants are genotyped using the previously identified flanking markers to find the plants with recombination events (recombinants). This results in new flanking markers and therefore a smaller mapping interval (Fig. 2).

1. Rinse seeds three times with tap water.

2. Soak seeds in $200 \mathrm{~mL}$ of $70 \%$ ethanol for $1 \mathrm{~min}$.

3. Inside a flow cabinet, remove ethanol and soak the seeds in $1.5 \%$ sodium hypochlorite for $15 \mathrm{~min}$ ( see Note 11 ).

4. Rinse seeds three times with sterile tap water to remove the sodium hypochlorite.

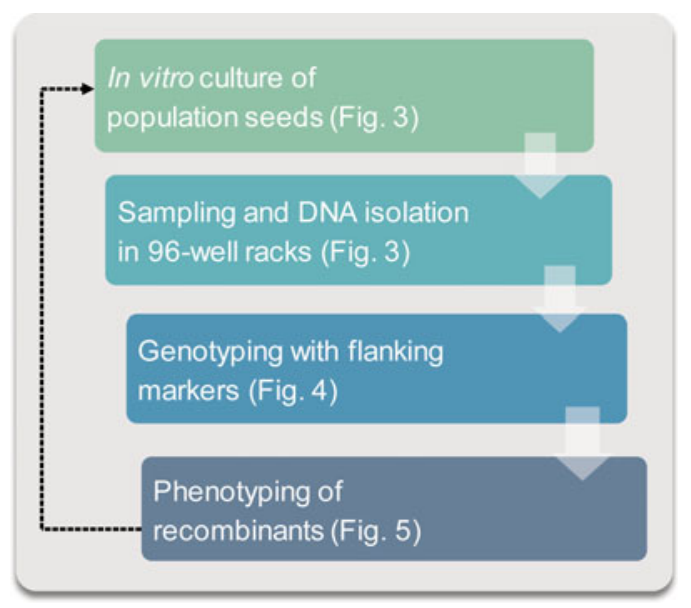

Fig. 2 Workflow for the high-throughput recombinant screening 
3.4.2 DNA Isolation in 96-Tube Racks
3.4.3 Genotyping
5. Sow the seeds on Murashige and Skoog [43] medium supplemented with $20 \mathrm{~g} / \mathrm{L}$ sucrose (MS20) and 100 ppm $\mathrm{GA}_{3}$ and incubate them in a climate room in the dark for 2 weeks (see Note 12).

6. Transfer the first emerging seedlings to a new pot with fresh MS20 medium. Place 24 plants in each pot and assign a unique number to each plant (Fig. 3).

7. Incubate the plants in a climate room for 2 weeks.

1. Fill a rack with two steel beads per well.

2. Inside a flow cabinet, take one leaf from the first plant of the first pot and place in position $\mathrm{Al}$ of the rack, and maintain the rack on ice during sampling. Fill each position in the rack with the samples from four pots (Fig. 3) (see Note 13).

3. Grind the samples using a TissueLyser at $25 \mathrm{~Hz}$ for $90 \mathrm{~s}$.

4. To add buffers, use a repeating pipette, and to transfer the aqueous phase to new tubes use an 8 -channel pipette.

5. Add $250 \mu \mathrm{L}$ of $\mathrm{CTAB}$ buffer to each sample, incubate at $65^{\circ} \mathrm{C}$ for $60 \mathrm{~min}$ ( $\mathrm{mix}$ by inversion occasionally), and cool the samples down on ice for $15 \mathrm{~min}$.

6. Add $250 \mu \mathrm{L}$ of chloroform:isoamyl alcohol (24:1). Mix by inversion and centrifuge at 4,000 rcf for $15 \mathrm{~min}$. In the meantime, prepare a new rack with clean tubes and add $200 \mu \mathrm{L}$ of isopropanol to each tube.

7. Transfer $200 \mu \mathrm{L}$ of the aqueous phase to the new tubes containing isopropanol, mix by inversion, and incubate at $-20{ }^{\circ} \mathrm{C}$ for $15 \mathrm{~min}$.

8. Centrifuge for $15 \mathrm{~min}$ at 4,000 $\mathrm{rcf}$, remove the supernatant, and wash the DNA pellets with $500 \mu \mathrm{L}$ of $70 \%$ ethanol.

9. Remove the ethanol and dry the pellets (see Note 14).

10. Add $100 \mu \mathrm{L}$ of Milli-Q water. To evaluate the purity and quantity of the DNA, analyze some random samples using a spectrophotometer ( see Note 15).

11. If needed, dilute the DNA to a final concentration of around $20 \mathrm{ng} / \mu \mathrm{L}$.

1. Analyze the entire rack with the two previously identified flanking markers (Subheading 3.3) to identify the recombinant plants (Fig. 4).

2. Design more molecular markers between the flanking markers.

3. Analyze the recombinants (see Subheading 3.4.4) and identify new flanking markers to narrow the mapping interval down. 

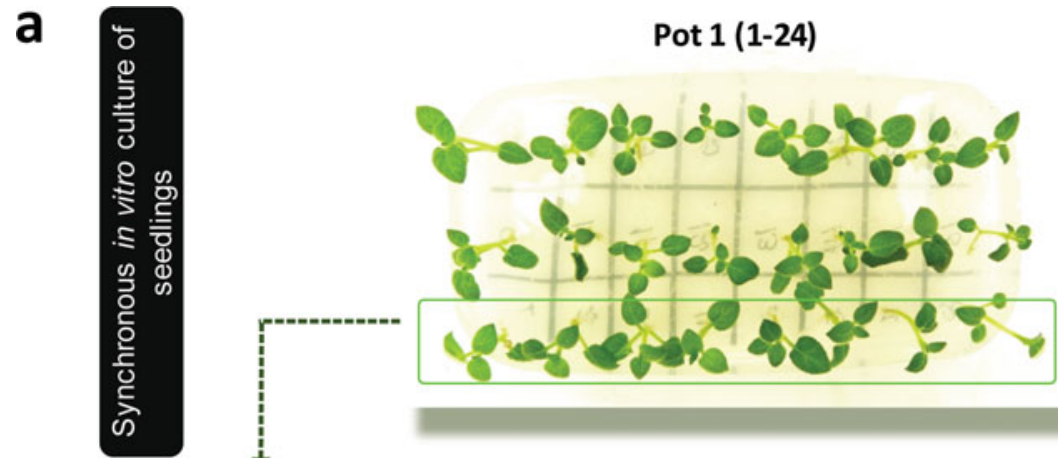

b
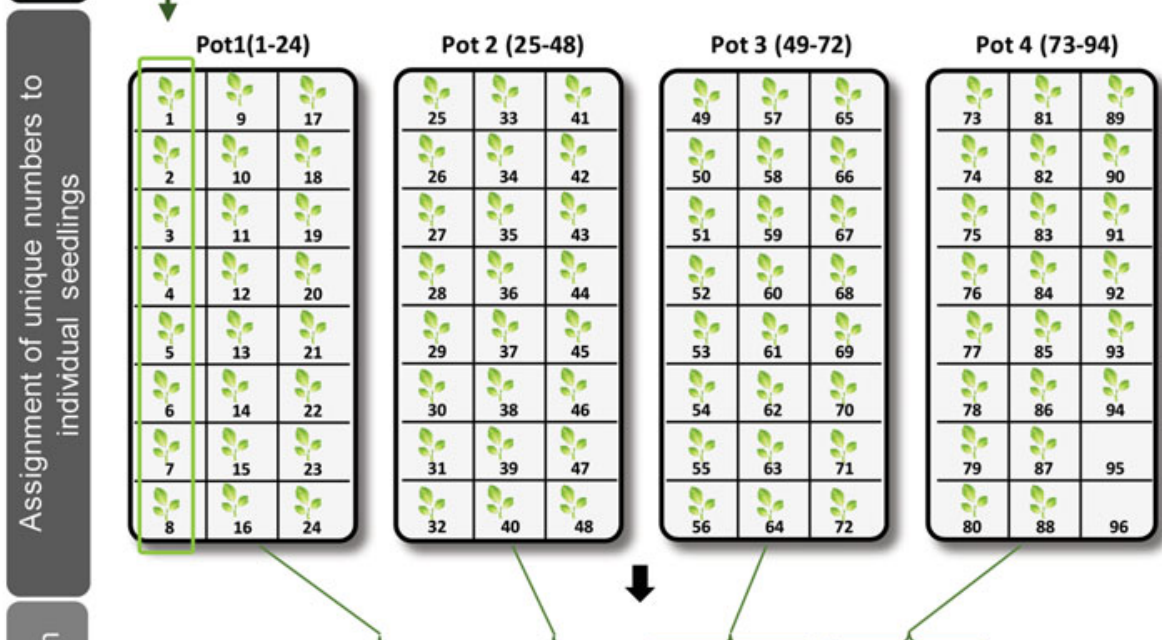

C

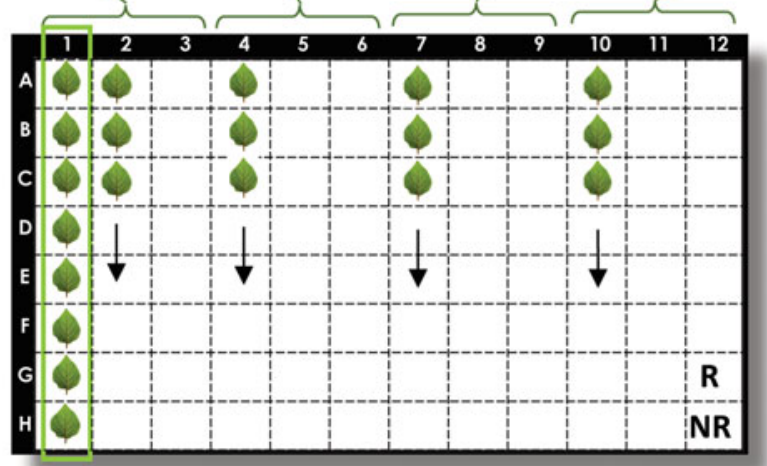

Fig. 3 In vitro culture and sampling for the high-throughput recombinant screening. (a) Seedling is transferred to pots with MS20 medium and organized in groups of 24 plants to grow them synchronously. (b) Each plant is assigned a unique number to track them along the process. Every four pots will form a 96 -well rack. (c) For each individual seedling, one leaf is collected for DNA isolation and transferred to a rack. The two last wells are filled with samples from the two parents (R and NR)

4. If needed, return to Subheading 3.4.1. This process should be iterated to fine map the immune receptor, until the mapping interval is small enough for selecting candidate genes (see Note 16). 
a

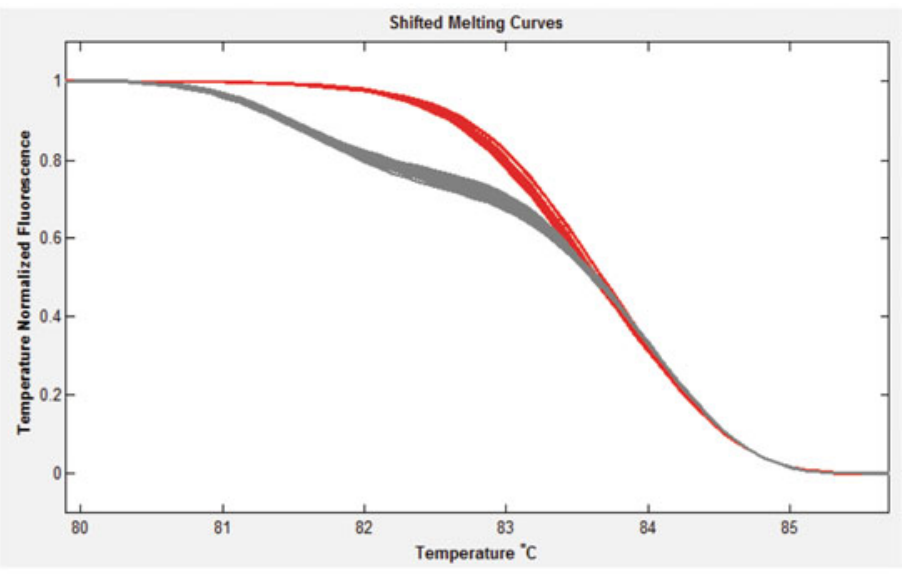

b

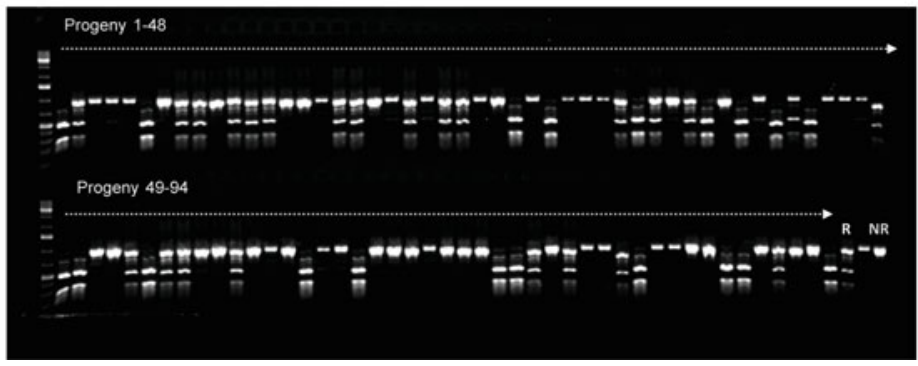

Fig. 4 Genotyping of the mapping population (plants 1-94 and parents). (a) HRM marker showing two patterns of melting curves (red or gray). The two different patterns indicate two groups with genotypes corresponding to the R or NR parent. (b) Gel image of the same plants tested with a CAPS marker, showing two different band patterns: three bands for the R parent (and progeny) and one band for the NR parent (and progeny)

3.4.4 Phenotyping of Recombinant Plants
1. Transfer the recombinant genotypes to pots containing fresh MS medium.

2. Micro-propagate and transfer two plants per genotype to the greenhouse.

3. Phenotype the recombinant plants using the method of your choice (Fig. 5 ).

4. Combine the genotypic and phenotypic information to determine the position of the recombination in relation to the flanking markers and target locus (Fig. 6). 
a

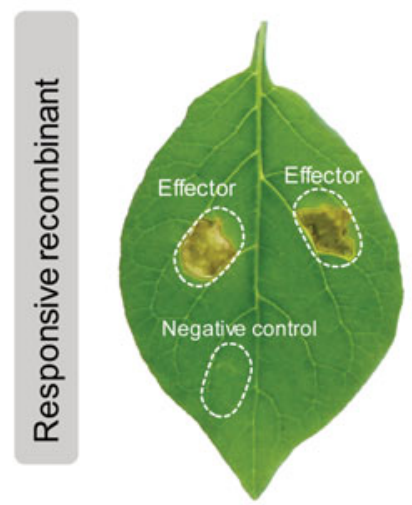

b

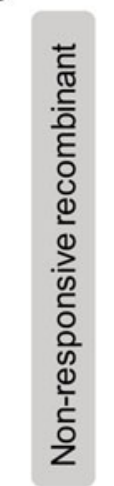

Upper leaf

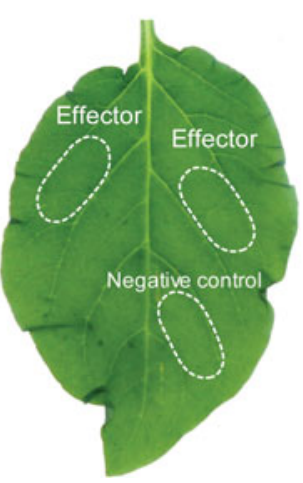

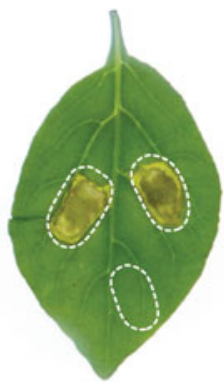

Middle leaf

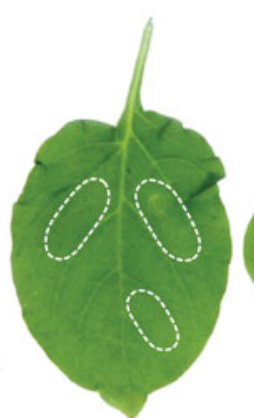

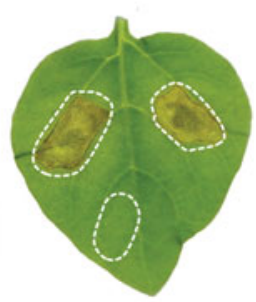

Lower leaf

Fig. 5 Phenotyping of recombinant plants for response to an effector. Three leaves from a recombinant are infiltrated with the effector in duplicate. A negative control is included. (a) Responsive recombinant that shows a clear hypersensitive response (HR) to the effector. (b) Nonresponsive recombinant, unable to recognize the effector, and no HR is observed

\section{Notes}

1. The required restriction enzymes entirely depend on the sequence of the target. Commonly used enzymes are EcoRI, BamHI, HindIII, RsaI, and DraI, among others.

2. To obtain the mapping population, sow around 100 seeds from the $\mathrm{Fl}$ in the greenhouse and phenotype them for the response to the effector or pathogen. If the $\mathrm{Fl}$ segregation is compatible with a $1: 1$ ratio, it indicates that the $\mathrm{R}$ parent has the immune receptor and that it is in heterozygous state. If the $\mathrm{Fl}$ does not show segregation, a backcross population $(\mathrm{BCl})$ is required, a $\mathrm{R}$ genotype from the progeny should be crossed with the NR parent, and the segregation ratio should be determined. If the segregation is indeed $1: 1$ in the $\mathrm{BCl}$, continue with this population. 


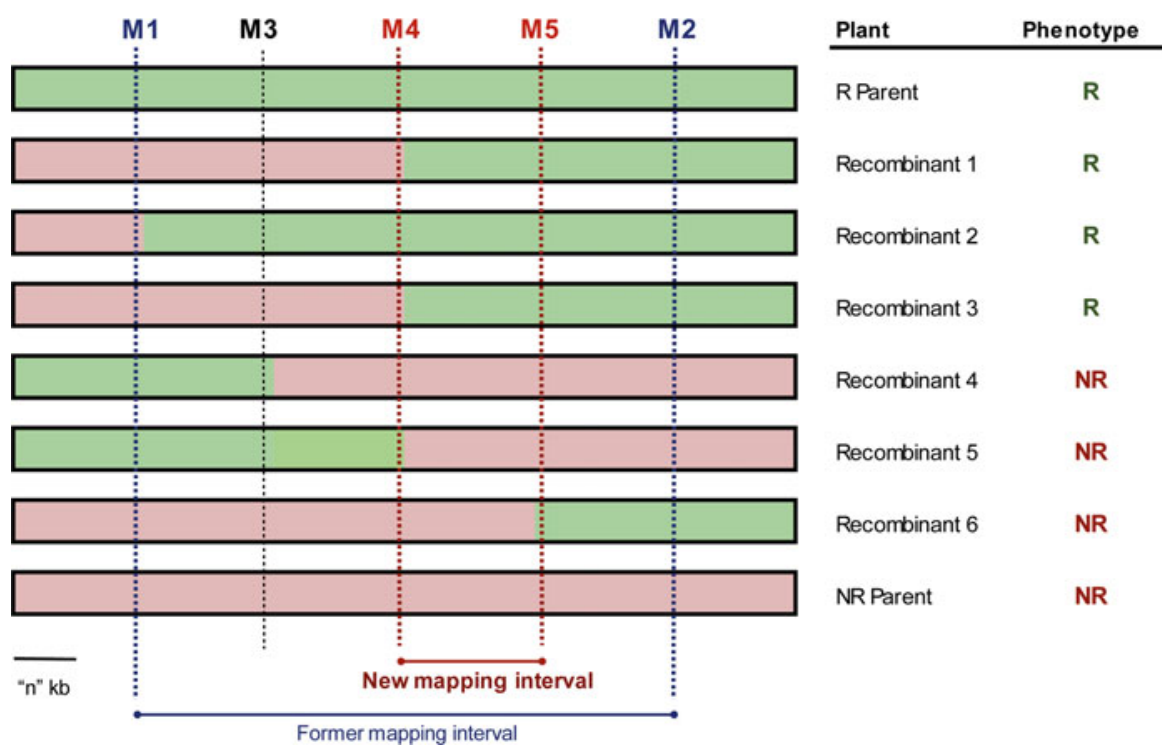

Fig. 6 Fine mapping. The markers M1 and M2 are used as flanking markers to identify recombination events and six recombinant plants (1-6) are identified. Then, new markers (M3, M4, and M5) are designed between the flanking markers and tested on the six recombinants and the parents. In parallel, the recombinants are phenotyped. Now, new flanking markers (M4 and M5) are identified and the mapping interval is narrowed down

3. The size of the mapping interval obtained from the BSR-Seq depends on the number of individuals per bulk, the sequencing depth, and the density of polymorphisms of the mapping population. For each parameter, more is better [35]. In our hands the BSR-Seq worked well using between 15 and 34 individuals per bulk.

4. RNA purity is determined measuring the OD ratios $260 / 280$ and $260 / 230$, which should be above 2.0 . The RNA integrity can be determined on an agarose gel, by evaluating the $28 \mathrm{~S}$ and $18 S$ rRNA bands.

5. For RNA isolation, it is possible to mix all the samples that form a bulk and then isolate the RNA from one sample. However, we consider it more appropriate to isolate the RNA from each sample, and then mix equal amounts of each to form the bulk RNA sample.

6. Generally, around $2 \mu \mathrm{g}$ of RNA is required for sequencing. The depth of the sequencing will depend on the number of individuals used per bulk. For 30 individuals per bulk, we used around 40 million paired-end reads (150 bp) per sample, corresponding to $12 \mathrm{Gbp}$ of raw sequencing data. 
7. The number of required molecular markers varies between experiments. The aim is to obtain markers that cover the complete mapping interval.

8. Before analyzing the entire population, test the markers in the parents and progeny with a known phenotype (use a subset of the plants included in the bulks). The selected markers are those that discriminate between $\mathrm{R}$ and NR plants. This test also gives information about the marker linkage phase.

9. For the HRM analysis, it is possible to genotype SNPs in bigger amplicons; however small amplicons allow for a better differentiation between variants. With bigger amplicons it is possible to detect additional mutations, which can result in more complex melting patterns that make it difficult to distinguish the variants [44].

10. Select the restriction enzyme that leads to clear differences in size between the cleaved and uncleaved PCR products.

11. After sterilizing the seeds of the mapping population, all the subsequent steps should be performed under sterile conditions.

12. Potato seeds are dormant directly after harvest, but will usually germinate rapidly after a period of cold storage for 6 months. The use of gibberellin hastens the onset of germination and can obviate the need for storing the seeds before sowing [45]. The timing and rate of germination depend on the population. In our hands, the required time for germination after GA treatment varies between 2 weeks and a few months, and the germination percentage is between $30 \%$ and $90 \%$.

13. Once the leaf sampling is done, keep the pots in a cold climate room $\left(18^{\circ} \mathrm{C}\right)$ until the recombinants are identified. In this way, the plants grow slowly, and it will be easier to keep them separated.

14. Dry the DNA pellet leaving the tubes open inside a fume hood, until residual ethanol has evaporated.

15. The DNA purity is determined by measuring the OD ratios $260 / 280$ and $260 / 230$, which should preferably (but not necessarily) be around 2.0 .

16. The final mapping interval should be small enough to end up with a manageable number of candidate genes for the next cloning steps. 


\section{References}

1. Stokstad E (2019) The new potato. Science 363(6427):574-577. https://doi.org/10. $1126 /$ science.363.6427.574

2. Food and Agriculture Organization of the United Nations (2017) FAOSTAT database. http://www.fao.org/faostat/en/\#data/QC

3. Simko I, Jansky S, Stephenson S, Spooner D (2007) Chapter 7-Genetics of resistance to pests and disease. In: Vreugdenhil D, Bradshaw J, Gebhardt C et al (eds) Potato biology and biotechnology. Elsevier Science B.V., Amsterdam, pp 117-155. https://doi. org/10.1016/B978-044451018-1/50049-X

4. Kirk W, Wharton P (2014) Chapter 11-Fungal and bacterial disease aspects in potato production. In: Navarre R, Pavek MJ (eds) The potato: botany, production and uses. $\mathrm{CAB}$ International, Washington, DC, pp 167-201. https://doi.org/10.1079/9781780642802. 0000

5. Jo KR, Zhu S, Bai Y, Hutten RCB, Kessel GJT, Vleeshouwers VGAA, Jacobsen E, Visser RGF, Vossen JH (2016) Problematic crops: 1. Potatoes. In: Plant pathogen resistance biotechnology. John Wiley \& Sons, Hoboken, NJ, pp 171-191. 9781118867716.ch9 https://doi.org/10.1002/

6. Haverkort AJ, Struik PC, Visser RGF, Jacobsen E (2009) Applied biotechnology to combat late blight in potato caused by Phytophthora infestans. Potato Res 52(3):249-264. https:// doi.org/10.1007/s1 1540-009-9136-3

7. Haverkort AJ, Boonekamp PM, Hutten R, Jacobsen E, Lotz LAP, Kessel GJT, Vossen JH, Visser RGF (2016) Durable late blight resistance in potato through dynamic varieties obtained by cisgenesis: scientific and societal advances in the DuRPh project. Potato Res 59(1):35-66. https://doi.org/10.1007/ s11540-015-9312-6

8. Jones JDG, Dangl JL (2006) The plant immune system. Nature 444(7117):323-329. https://doi.org/10.1038/nature05286

9. Dodds PN, Rathjen JP (2010) Plant immunity: towards an integrated view of plant-pathogen interactions. Nat Rev Genet 11(8):539-548. https://doi.org/10.1038/nrg2812

10. Wang Y, Tyler BM, Wang Y (2019) Defense and counterdefense during plant-pathogenic oomycete infection. Annu Rev Microbiol 73 (1):667-696. https://doi.org/10.1146/ annurev-micro-020518-120022

11. Du J, Vleeshouwers VGAA (2017) New strategies towards durable late blight resistance in potato. In: Kumar Chakrabarti S, Xie C, Kumar
Tiwari J (eds) The potato genome. Springer International Publishing, Cham, pp 161-169. https://doi.org/10.1007/978-3-319-661353_10

12. Vleeshouwers VG, Raffaele S, Vossen JH, Champouret $\mathrm{N}$, Oliva $\mathrm{R}$, Segretin ME, Rietman H, Cano LM, Lokossou A, Kessel G, Pel MA, Kamoun S (2011) Understanding and exploiting late blight resistance in the age of effectors. Annu Rev Phytopathol 49:507-531. https://doi.org/10.1146/annurev-phyto072910-095326

13. Du J, Verzaux E, Chaparro-Garcia A, Bijsterbosch G, Keizer LC, Zhou J, Liebrand TW, Xie C, Govers F, Robatzek S, van der Vossen EA, Jacobsen E, Visser RG, Kamoun S, Vleeshouwers VG (2015) Elicitin recognition confers enhanced resistance to $\mathrm{Phy}$ tophthora infestans in potato. Nat Plants 1 (4):15034. https://doi.org/10.1038/ nplants.2015.34

14. Zhu S, Li Y, Vossen JH, Visser RGF, Jacobsen E (2012) Functional stacking of three resistance genes against Phytophthora infestans in potato. Transgenic Res 21(1):89-99. https:// doi.org/10.1007/s11248-011-9510-1

15. Boschi F, Schvartzman C, Murchio S, Ferreira V, Siri MI, Galván GA, Smoker M, Stransfeld L, Zipfel C, Vilaró FL, Dalla-Rizza $M$ (2017) Enhanced bacterial wilt resistance in potato through expression of Arabidopsis EFR and introgression of quantitative resistance from Solanum commersonii. Front Plant Sci 8 (1642). https://doi.org/10.3389/fpls.2017. 01642

16. Kunwar S, Iriarte F, Fan Q, Evaristo da Silva E, Ritchie L, Nguyen NS, Freeman JH, Stall RE, Jones JB, Minsavage GV, Colee J, Scott JW, Vallad GE, Zipfel C, Horvath D, Westwood J, Hutton SF, Paret ML (2018) Transgenic expression of EFR and Bs2 genes for field management of bacterial wilt and bacterial spot of tomato. Phytopathology ${ }^{\mathrm{TM}} \quad 108$ (12):1402-1411. https://doi.org/10.1094/ phyto-12-17-0424-r

17. Wan W-L, Fröhlich K, Pruitt RN, Nürnberger T, Zhang L (2019) Plant cell surface immune receptor complex signaling. Curr Opin Plant Biol 50:18-28. https://doi.org/ 10.1016/j.pbi.2019.02.001

18. Ruiz de Galarreta JI, Carrasco A, Salazar A, Barrena I, Iturritxa E, Marquinez R, Legorburu FJ, Ritter E (1998) Wild Solanum species as resistance sources against different pathogens of potato. Potato Res 41(1):57-68. https://doi.org/10.1007/bf02360262 
19. Vleeshouwers VGAA, Rietman H (2008) In planta expression systems. In: Lamour SK (ed) Oomycete genetics and genomics. John Wiley \& Sons, Inc., Hoboken, NJ, pp 455-475. https://doi.org/10.1002/ 9780470475898.ch23

20. Du J, Vleeshouwers VGAA (2014) The do's and don'ts of effectoromics. In: Birch P, Jones JT, Bos JIB (eds) Plant-pathogen interactions: methods and protocols. Humana Press, Totowa, NJ, pp 257-268. https://doi.org/ 10.1007/978-1-62703-986-4_19

21. Domazakis E, Lin X, Aguilera-Galvez C, Wouters D, Bijsterbosch G, Wolters PJ, Vleeshouwers VGAA (2017) Effectoromics-based identification of cell surface receptors in potato. In: Shan L, He P (eds) Plant pattern recognition receptors: methods and protocols. Springer, New York, pp 337-353. https://doi. org/10.1007/978-1-4939-6859-6_29

22. Ballvora A, Ercolano MR, Weiß J, Meksem K, Bormann CA, Oberhagemann P, Salamini F, Gebhardt C (2002) The Rl gene for potato resistance to late blight (Phytophthora infestans) belongs to the leucine zipper/NBS/ LRR class of plant resistance genes. Plant J 30 (3):361-37l. https://doi.org/10.1046/j. 1365-313X.2001.01292.x

23. Van Der Vossen E, Sikkema A, Hekkert BL, Gros J, Stevens P, Muskens M, Wouters D, Pereira A, Stiekema W, Allefs S (2003) An ancient $\mathrm{R}$ gene from the wild potato species Solanum bulbocastanum confers broadspectrum resistance to Phytophthora infestans in cultivated potato and tomato. Plant J 36 (6):867-882. https://doi.org/10.1046/j. 1365-313X.2003.01934.x

24. van der Vossen EAG, Gros J, Sikkema A, Muskens M, Wouters D, Wolters P, Pereira A, Allefs S (2005) The Rpi-blb2 gene from Solanum bulbocastanum is an $\mathrm{Mi}-\mathrm{l}$ gene homolog conferring broad-spectrum late blight resistance in potato. Plant J 44(2):208-222. https://doi.org/10.1111/j.1365-313X. 2005.02527.x

25. Vleeshouwers VGAA, Rietman H, Krenek P, Champouret N, Young C, Oh S-K, Wang M, Bouwmeester K, Vosman B, Visser RGF, Jacobsen E, Govers F, Kamoun S, Van der Vossen EAG (2008) Effector genomics accelerates discovery and functional profiling of potato disease resistance and Phytophthora Infestans avirulence genes. PLoS One 3(8): e2875. https://doi.org/10.1371/journal. pone. 0002875

26. Scheible W-R, Törjek O, Altmann T (2005) From markers to cloned genes: map-based cloning. In: Lörz H, Wenzel G (eds) Molecular marker systems in plant breeding and crop improvement. Springer, Berlin, pp 55-86. https://doi.org/10.1007/3-540-26538-4_4

27. Hamilton JP, Robin Buell C (2012) Advances in plant genome sequencing. Plant $\mathrm{J} 70$ (1):177-190. https://doi.org/10.1111/j. 1365-313X.2012.04894.x

28. Edwards D, Batley J (2010) Plant genome sequencing: applications for crop improvement. Plant Biotechnol J 8(1):2-9. https:// doi.org/10.1111/j.1467-7652.2009. 00459.x

29. Xu X, Pan S, Cheng S, Zhang B, Mu D, Ni P, Zhang G, Yang S, Li R, Wang J, Orjeda G, Guzman F, Torres M, Lozano R, Ponce $O$, Martinez D, De la Cruz G, Chakrabarti SK, Patil VU, Skryabin KG, Kuznetsov BB, Ravin NV, Kolganova TV, Beletsky AV, Mardanov AV, Di Genova A, Bolser DM, Martin DMA, Li G, Yang Y, Kuang H, Hu Q, Xiong X, Bishop GJ, Sagredo B, Mejía N, Zagorski W, Gromadka R, Gawor J, Szczesny P, Huang S, Zhang Z, Liang C, He J, Li Y, He Y, Xu J, Zhang Y, Xie B, Du Y, Qu D, Bonierbale M, Ghislain $M$, del Rosario Herrera $M$, Giuliano G, Pietrella M, Perrotta G, Facella P, O'Brien K, Feingold SE, Barreiro LE, Massa GA, Diambra L, Whitty BR, Vaillancourt B, Lin H, Massa AN, Geoffroy M, Lundback S, DellaPenna D, Robin Buell C, Sharma SK, Marshall DF, Waugh R, Bryan GJ, Destefanis M, Nagy I, Milbourne D, Thomson SJ, Fiers M, Jacobs JME, Nielsen KL, Sønderkær M, Iovene M, Torres GA, Jiang J, Veilleux RE, Bachem CWB, de Boer J, Borm T, Kloosterman B, van Eck H, Datema E, te Lintel HB, Goverse A, van Ham RCHJ, Visser RGF, The Potato Genome Sequencing C, The Potato Genome C, Shenzhen BGI, Cayetano Heredia U, Central Potato Research I, Centre Bioengineering RAS, Cgr-Cmm UdC, College of Life Sciences UoD, High Technology Research Center SAoAS, Huazhong Agriculture U, Hunan Agricultural U, Imperial College L, Instituto de Investigaciones A, Institute of B, Biophysics, Institute of V, Flowers CAoAS, International Potato C, Italian National Agency for New Technologies E, Sustainable D, Institute JCV, Laboratorio de Agrobiotecnología INdTA, Laboratorio de Biología de Sistemas UNdL, Michigan State U, Scottish Crop Research I, Teagasc Crops Research C, The New Zealand Institute for P, Food Research L, University of A, University of W, Virginia Polytechnic I, State U, Wageningen U, Research C (2011) Genome sequence and analysis of the tuber crop potato. Nature 475(7355):189-195. https://doi.org/ $10.1038 /$ nature 10158 
30. Sharma SK, Bolser D, de Boer J, Sønderkær M, Amoros W, Carboni MF, D'Ambrosio JM, de la Cruz G, Di Genova A, Douches DS, Eguiluz M, Guo X, Guzman F, Hackett CA, Hamilton JP, Li G, Li Y, Lozano R, Maass A, Marshall D, Martinez D, McLean K, Mejía N, Milne L, Munive S, Nagy I, Ponce $\mathrm{O}$, Ramirez M, Simon R, Thomson SJ, Torres Y, Waugh R, Zhang Z, Huang S, Visser RGF, Bachem CWB, Sagredo B, Feingold SE, Orjeda G, Veilleux RE, Bonierbale M, Jacobs JME, Milbourne D, Martin DMA, Bryan GJ (2013) Construction of reference chromosome-scale pseudomolecules for potato: integrating the potato genome with genetic and physical maps. G3: Genes|Genomes|Genetics 3(11):2031-2047. https:// doi.org/10.1534/g3.113.007153

31. Hardigan MA, Crisovan E, Hamilton JP, Kim J, Laimbeer P, Leisner CP, ManriqueCarpintero NC, Newton L, Pham GM, Vaillancourt B, Yang X, Zeng Z, Douches DS, Jiang J, Veilleux RE, Buell CR (2016) Genome reduction uncovers a large dispensable genome and adaptive role for copy number variation in asexually propagated Solanum tuberosum. Plant Cell 28(2):388-405. https://doi.org/10. $1105 /$ tpc. 15.00538

32. Witek K, Jupe F, Witek AI, Baker D, Clark MD, Jones JDG (2016) Accelerated cloning of a potato late blight-resistance gene using RenSeq and SMRT sequencing. Nat Biotechnol 34(6):656-660. https://doi.org/10. $1038 /$ nbt. 3540

33. Michelmore RW, Paran I, Kesseli RV (1991) Identification of markers linked to diseaseresistance genes by bulked segregant analysis: a rapid method to detect markers in specific genomic regions by using segregating populations. Proc Natl Acad Sci 88(21):9828-9832. https://doi.org/10.1073/pnas.88.21.9828

34. Zou C, Wang P, Xu Y (2016) Bulked sample analysis in genetics, genomics and crop improvement. Plant Biotechnol J 14 (10):1941-1955. https://doi.org/10.1111/ pbi.12559

35. Liu S, Yeh CT, Tang HM, Nettleton D, Schnable PS (2012) Gene mapping via bulked segregant RNA-Seq (BSR-Seq). PLoS One 7 (5):e36406. https://doi.org/10.1371/jour nal.pone.0036406

36. Edae EA, Rouse MN (2019) Bulked segregant analysis RNA-seq (BSR-Seq) validated a stem resistance locus in Aegilops umbellulata, a wild relative of wheat. PLoS One 14(9):e0215492. https://doi.org/10.1371/journal.pone. 0215492

37. Dakouri A, Zhang X, Peng G, Falk KC, Gossen BD, Strelkov SE, Yu F (2018) Analysis of genome-wide variants through bulked segregant RNA sequencing reveals a major gene for resistance to Plasmodiophora brassicae in Brassica oleracea. Sci Rep 8(1):17657. https://doi. org/10.1038/s41598-018-36187-5

38. Ramirez-Gonzalez RH, Segovia V, Bird N, Fenwick P, Holdgate S, Berry S, Jack P, Caccamo M, Uauy C (2015) RNA-Seq bulked segregant analysis enables the identification of high-resolution genetic markers for breeding in hexaploid wheat. Plant Biotechnol J 13 (5):613-624. https://doi.org/10.1111/pbi. 12281

39. Wang Z, Gerstein M, Snyder M (2009) RNA-Seq: a revolutionary tool for transcriptomics. Nat Rev Genet 10(1):57-63. https:// doi.org/10.1038/nrg2484

40. Lin X (2018) Apoplastic effectors, MAMPs and surface immune receptors-the battlefront of the Phytophthora infestans-potato interaction. PhD thesis, Wageningen University.

41. Chen S, Zhou Y, Chen Y, Gu J (2018) fastp: an ultra-fast all-in-one FASTQ preprocessor. Bioinformatics 34(17):i884-i890. https://doi. org/10.1093/bioinformatics/bty560

42. Dobin A, Davis CA, Schlesinger F, Drenkow J, Zaleski C, Jha S, Batut P, Chaisson M, Gingeras TR (2012) STAR: ultrafast universal RNA-seq aligner. Bioinformatics 29(1):15-21. https:// doi.org/10.1093/bioinformatics/bts635

43. Murashige T, Skoog F (1962) A revised medium for rapid growth and bioassays with tobacco tissue cultures. Physiol Plantarum 15:473-497

44. Liew M, Pryor R, Palais R, Meadows C, Erali M, Lyon E, Wittwer C (2004) Genotyping of single-nucleotide polymorphisms by high-resolution melting of small amplicons. Clin Chem 50(7):1156-1164. https://doi. org/10.1373/clinchem.2004.032136

45. Simmonds NW (1963) Experiments on the germination of potato seeds. I. Eur Potato J 6 (1):45-60. https://doi.org/10.1007/ bf02364634 